\title{
「WE-NET」プロジェクトについて 極低温材料技術の開発一*
}

堀 谷 貴 雄**

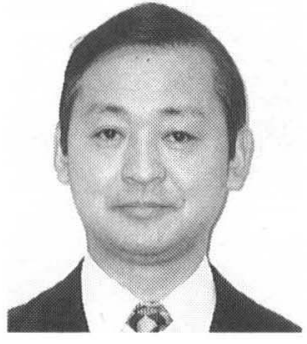

1. は じめに

$\ulcorner\mathrm{WE}-\mathrm{NET}$ 」プロジェクトは, 平成 5 年に通産省工業 技術院の「ニューサンシャイン計画」の一環としてスター トしたもので, 水力, 太陽光などの再生可能なエネルギー を利用してクリーンエネルギーである水素を製造し，そ れを輸送可能な媒体に変換してエネルギー多消費地域に 輸送し，利用する技術を開発することにより，世界的規 模のエネルギーの有効利用を図ろうとするものである. これまで水素エネルギー関連の国際大型プロジェクトと しては, カナダの水力利用の電力をもとに水素を製造し, 欧州へ運ほうという「EQHHPP」プロジェクトや, サウ アラビアとドイツが共同で行っている太陽光発電からの 水素製造，それらの輸送，利用技術の開発を目指す

「HYSOLAR」プロジェクトなどがあるが，いずれも現 在は一段落, または休止状態にあり, 日本の「WE-NET」 プロジェクトが最近では最も活発な活動をおこなってい る. 昨年 6 月にドイツのシュツットガルトで開催された 第 11 回水素エネルギー国際会議 (11 th WHEC) でも, 本プロジェクトからの発表が 16 件もあり, その開発動向 は世界の注目を浴びつつある。

本プロジェクトは, 図 1 に示すように通商産業省工業 技術院ニューサンシャイン計画推進本部の指導のもと NEDO（新エネルギー・産業技術総合開発機構）が中立 期間に各開発項目を委託し，委託を受けた機関がさらに 各企業に再委託するという開発体制で推進されている。

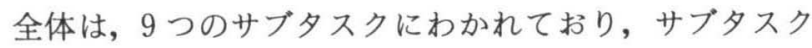
1〜3 はソフト面での技術開発や評価を, サブタスク 4〜9 は主にハード面での技術開発をすすめることになってい

\footnotetext{
*原稿受付 平成 8 年 12 月 2 日

JRCM（金属系材料研究開発センター） Japan Reserch and Development Center for Metals
}

る.（財）金属系材料研究開発センター (JRCM) はこの うち「サブタスク $6 」$ の液体水素温度 $(20 \mathrm{~K})$ で使用され る低温材料の研究・開発に関し NEDO より委託を受け, 再委託会社 7 社 (愛知製鋼, IHI, 新日本製鐵, 住友金属 工業, 日本製鋼所, 古河電気工業, 三菱重工業）ととも に開発を進めている.

ここでは, 本プロジェクトの概要とサブタスク 6 のこ れまでの研究開発状況について解説する.

\section{2. 「WE-NET」プロジェクトの概要}

$\ulcorner\mathrm{WE}-\mathrm{NET}$ 」プロジェクトは, 2020 年までの 28 年間 を 3 期に分けて開発を進める予定で, 第 I 期 (H 5 H 10）では水素製造技術，水素輸送・貯蔵技術，水素利用 技術などに関する基礎的技術の確立を図るとともに，第 II 期以降に予定されているパイロットプラントの設計, 製造に必要な技術を確立することになっている.

本プロジェクトでは, 水素の製造から利用までの広範 囲でかつ高レベルの技術の確立を目指している。例えば, 水素製造技術では高効率の「固体高分子電解質電解法」 を用いて, 電流密度 $1 \mathrm{~A} / \mathrm{cm}^{2}$ 以上, エネルギー効率 $90 \%$ を維持する $2500 \mathrm{~cm}^{2}$ の電解セルを実現することを目指 している，また，水素燃焼タービンの技術では，タービ ン入口温度が $1700^{\circ} \mathrm{C}$, 発電端効率 $60 \%$ 以上という高効 率が達成できるサイクルの開発を行っている。さらに， スケールメリットを出すため水素液化装置は約 $300 \mathrm{t} / \mathrm{d}$ (現状： $30 \mathrm{t} / \mathrm{d}$ が最高), 水素燃焼夕ービンが 1 基あたり $500 \mathrm{MW}$ 程度の出力を想定した開発が実施されており, それに伴い液体水素貯蔵タンクや輸送タンカーも非常に 大型のものが考えられている．現在のところ貯蔵タンク は約 5 万 $\mathrm{m}^{3}$, 輸送タンカーは $15 \sim 20$ 万 $\mathrm{m}^{3}$ の大きさのも のが想定されている。貯蔵タンクについては, 現在国内 が $540 \mathrm{~m}^{3}$ (NASDA 設置), 国外は $3200 \mathrm{~m}^{3}$ (NASA 設置) 


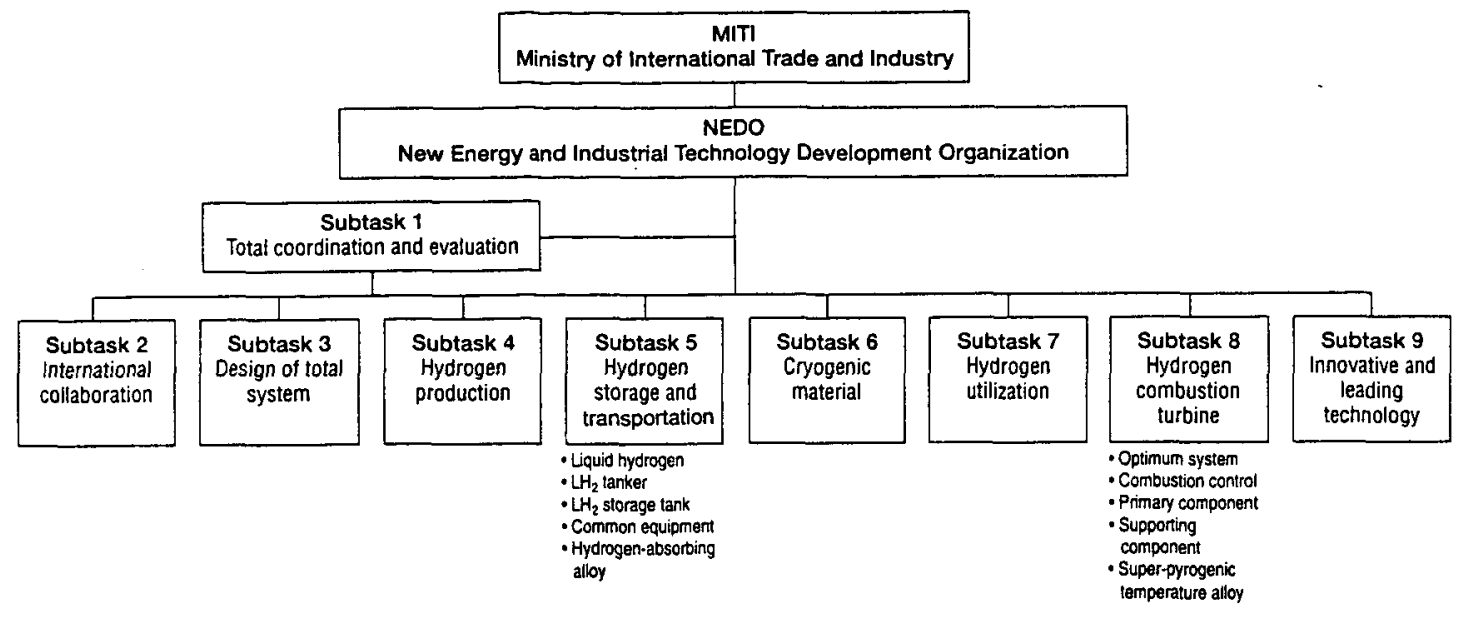

图1「水素利用国際クリーンエネルギーシステム技術（WE-NET）」

のものが最大であり，本プロジェクトで計画しているも のははるかに大型のものになっている.

ところで本プロジェクトでは，水素の製造場所は電力 の安価な国外を想定しており，したがって，製造現地で 水素を運搬しやすい形に変換した後, 日本へ輸送される 予定である。輸送時の水素の形態については，現在種々 のもの（液体水素，メタノール，アンモニアなど）が検 討されているが, 今のところコストの面からは液体水素 が最も有望である。したがって，水素を液化する現地お よび日本の港には液体水素の貯蔵タンクが, また液体水 素の輸送にはタンカーが必要となる.サブタスク 5 では, これまで貯蔵タンクや輸送タンカーの概念設計を進めて きており，貯蔵タンク関連では，地上貯槽および地下貯 槽の基本設計, また LNG 貯蔵タンク並の B. O. R.（蒸 発率）を確保するための各種断熱構造などについて検討 している，また，輸送タンカー関連では，搭載する球形 および角形貯蔵タンクの構造, タンクの断熱法および支 持方法などについて基本検討を進めている、サブタスク 6 では,これらの大量貯蔵, 輸送システムで使用される大 型構造物の低温材料の開発を委託されており，特に液体 水素温度域での優れた破壊・疲労特性と耐水素脆化特性 の両立に着眼した研究開発が不可欠であると考えて開発 を進めている。これは，構造物が大型になると材料の板 圧が大きくなり，溶接部やコーナー部での応力集中が増 大するため, 耐破燷特性や耐水素脆化特性がいつそう簃 しく求められるためである。

\section{3. サブタスク 6 のこれまでの研究成果}

液体水素温度域での材料特性に関する研究は, 液体燃 料ロケット開発の要素技術としてアメリカ及び旧ソ連邦 を中心に 1960-1970年代に大規模に実施され，既存材料 の基本的な特性はおおむね把握されたと推察される。し かし, 大型構造物に必要な溶接構造を含む厚肉材料の破 壊勒性や疲労特性については，まだほとんど把握されて いない，また，国内では $110 \mathrm{~K}$ の LNG(液化天然ガス)
タンク用材料の実績は多いものの，液体水素温度領域で の材料評価は国産ロケット開発に関連して比較的薄肉の 材料について一部実施されたにすぎず，わずかに超伝導 技術に関連して液体 $\mathrm{He}$ 温度域での各種試験が行われて いるのが実状である。

一方, 水素脆化に関しては,これまで常高温域でのデー 夕が数多く報告されている，本プロジェクトの操業温度 は室温〜20 K の低温であり，これらの温度での水素脆化 はほとんど生じないと考えられるが，低温でも鞀性に影 響するという報告もある。また，室温以下の温度域での 水素の金属材料中への侵入挙動を始め，極低温域での水 素脆化挙動の詳細はまだ解明されておらず，多くの課題 が残されていると思われる。

サブタスク 6 では以上の背景を踏まえ, 本プロジェク トの第 I 期においては,

(1) 液体水素条件で使用できる候補材の選定

(2) 最適溶接法および溶接条件の確立

(3) 液体水素温度での材料データの蓄積 を目標に挙げ, 研究開発を進めている。

研究開発のスタートである平成 5 年には主に既存低温 材料の極低温（<20K）における特性データの収集と評 価方法に関する調查を実施し，以下のことが明らかに なった。

(1) 液体水素温度域の材料の機械的特性デー夕は比較 的少なく，特に溶接部のデータは非常に少ない.世界的 にもデータのある研究機関が限られている。

(2) 極低温での水素脆化に関するデータも同様に少な く，特に低温用材料のデータが少ない.

(3) 液体水素用の構造部材には, 従来はオーステナイト $(\gamma)$ 系ステンレス鋼やアルミニウム $(\mathrm{Al})$ 合金などが使 用されている。

上記の調査結果をもとに，平成 6 年度からは既存材料 から候補材料を選び，厚板材の特に溶接部について，低 温脆化および水素脆化に関する系統的な試験を開始し， 構造材料としての評価と材料データの蓄積を図ってい 
る.

候補材料としては, 液体 $\mathrm{He}$ 温度 $(4 \mathrm{~K})$ での使用実績 の多い $\gamma$ 系ステンレス鋼の SUS $304 \mathrm{~L}$ と SUS $316 \mathrm{~L}$, ま た LNG タンカーで使用実績のある非熱処理型の $\mathrm{Al}$ 合 金 A 5083，の計 3 種を選定した。評価試験では, 低温脆 化，水素脆化挙動に大きな影響を及浑す溶接条件と金属 中の水素量に特に注目し, それらを変化させたときの脆 化感受性を検討している。

実験方法は，まず各候補材の $25 \mathrm{~mm}$ の厚板を用いて， 最も一般的な溶接法, すなわちステンレス鋼は TIG 法, $\mathrm{Al}$ 合金は MIG 法で溶接継手を作成し，母材および溶接 部から試験片を採取した。また，ステンレス鋼では溶接 金属中の $\delta$ フェライト量を $0 \sim 10 \%$ に変化させ, $\mathrm{Al}$ 合金 では溶接金属中の介在物の形状，分布を変化させるため 溶接時の入熱量を変化させた.

水素脆化感受性は, 高温高圧のオートクレイブ中での 水素チャージ処理により各試験片に水素をコントロール しながら添加した後，機械試験を実施して評価した．添 加量は, 水素脆化挙動を明確に把握するため, 通常の操 業条件下で予想される水素侵入量よりかなり多くした。 添加後の水素量は, ステンレス鋼では $10 \sim 30 \mathrm{ppm}, \mathrm{Al}$ 合

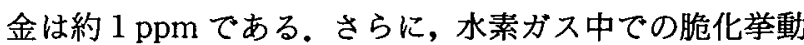
を検討するため，高圧水素ガス雰囲気下（1 および 10 Mpa）で引張および疲労試験を行った。

また各試験は，液体水索温度 $(20 \mathrm{~K})$ ての試験が可能 な試験機がほとんどないため, 既設の液体 $\mathrm{He}$ 温度 $(4 \mathrm{~K})$ 試験機を用いて $4 \mathrm{~K}$ および室温で実施した。

以下にこれまで得られた結果の概要を示す。

(1) ステンレス鋼 (SUS $304 \mathrm{~L}$, SUS $316 \mathrm{~L}$ )

(1) 引張特性

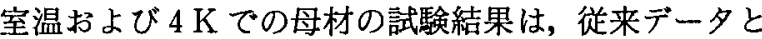
同等であった，極低温域では引張強さが常温の 3 倍近く 高くなる反面，伸び，絞りはやや低下する傾向にある。 また，水素チャージ量の增加に伴いSUS $304 \mathrm{~L} て ゙$ 室温の 伸び，絞りが低下する傾向があるものの，両鋼とも $4 \mathrm{~K}$ での特性には水素チャージ量の影響がほとんど認められ

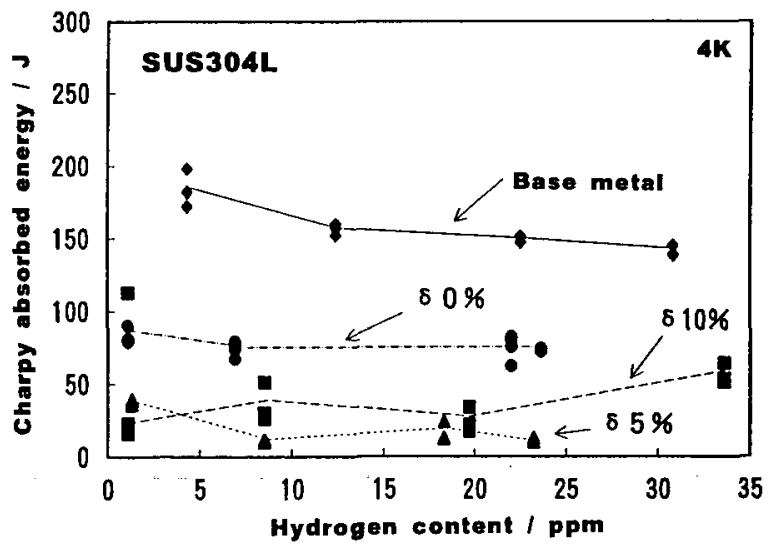

図 2 SUS $304 \mathrm{~L}$ 鋼の母材及び溶接金属の $4 \mathrm{~K}$ のシャル ピー衝撃值に及ぽす水装チャージ量の影響
ず，構造材料として十分な特性を保持していると考えら れる。

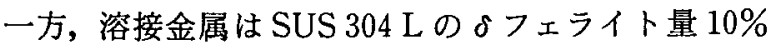
および $5 \%$ 材では水素チャージ量の増加に伴い伸び，絞 り值がやや低下する傾向を示したが，それ以外では水点 チャージによる脆化洁認められなかった。また，両鋼の 溶接材料ともに $\delta$ フェライト量低減による延性の改善

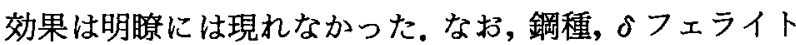

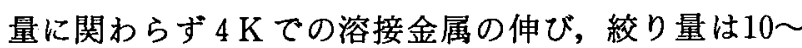
30\%でいずれも母材より低い値を示した。

(2) シャルピ一衝撃特性

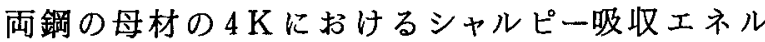
ギーは室温に比へて $20 \%$ 程度低下する，また，試験温度 によらず水素チャージ量による吸収エネルギーの変化は 母材では顕著に認められなかった。

溶接金属の場合, $4 \mathrm{~K}$ 試験材や水素チャージ材で脆化

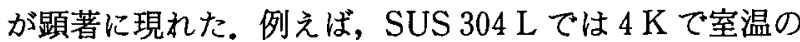
吸収エネルギーの $15 \%$ にてて低下し(図2), SUS 316 L では水素チャージ材は水菜チャージ前の約 $50 \%$ まで低

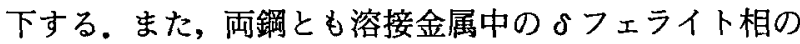
増加に伴い, 低温脆化感受性が大きくなる傾向を示した。

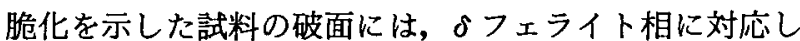
た部分が認められることから，溶接金属の水素脆化，低 温脆化に $\delta$ フェライトの生成が関与していると思われ る.

\section{(3) 破壊勒性}

母材及び溶接金属の破壊靬性 $\left(\mathrm{K}_{\mathrm{Ic}}(\mathrm{J})\right)$ に及ほす影響 を評価した，両鋼の母材は延性破壊を示し，水素チャー ジの有無に関わらず $250 \mathrm{MPa} ・ \mathrm{~m}^{1 / 2}$ 以上の良好な值を示 した.このうち，SUS 304 L の室温において水素チャー ジによる破壊勒性值の低下と破面形態の恋化が認められ た。

溶接金属では，室温では水素チャージによる $\mathrm{K}_{\mathrm{IC}}(\mathrm{J})$ の低下と破面形態の変化が認められた，4Kではいずれ

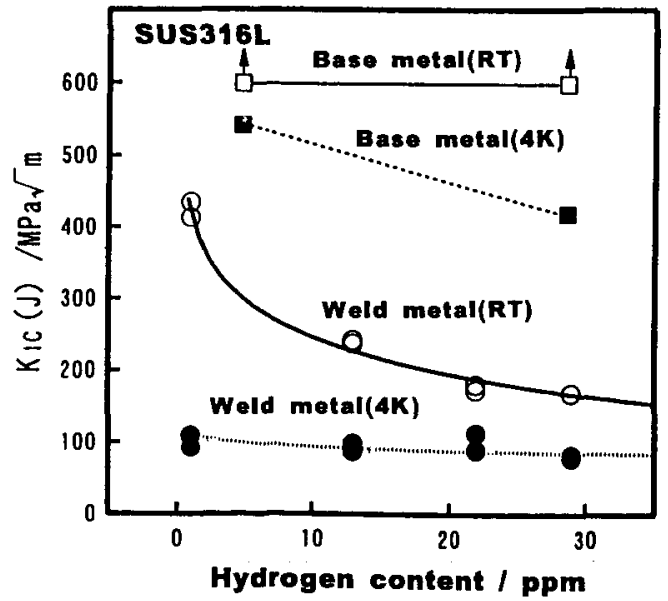

図 3 SUS $316 \mathrm{~L}$ 鋼の母材及び溶接金属（ $\delta$ 量：

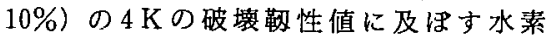
チャージ量の影響 
表 1 候補材の低温脆化評価試験結果のまとめ

\begin{tabular}{|c|c|c|c|c|c|c|c|c|c|c|}
\hline \multirow{3}{*}{ Materials } & \multirow{3}{*}{ siltl } & \multicolumn{9}{|c|}{ Mechankal properties } \\
\hline & & \multicolumn{2}{|c|}{$\begin{array}{l}\text { Tensile } \\
\text { strength }\end{array}$} & \multicolumn{2}{|c|}{$\begin{array}{l}\text { Elongation } \\
\text { and } \\
\text { reduction } \\
\text { of area }\end{array}$} & \multicolumn{2}{|c|}{$\begin{array}{l}\text { Charpy } \\
\text { absorped } \\
\text { energy }\end{array}$} & \multicolumn{2}{|c|}{$\begin{array}{l}\text { Fracture } \\
\text { lowghness }\end{array}$} & \multirow{2}{*}{ 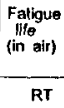 } \\
\hline & & $\mathrm{RT}$ & $4 \mathrm{~K}$ & RT & $4 \mathrm{~K}$ & RT & $4 \mathrm{~K}$ & RT & $4 \mathrm{~K}$ & \\
\hline \multirow{2}{*}{$\begin{array}{c}S 304 L \\
\left(F_{\theta}-18 C C_{-}-8 N i\right)\end{array}$} & Base metal & 8 & $\circ$ & B & 0 & B & 0 & B & 0 & 8 \\
\hline & $\begin{array}{l}\text { Weld metal } \\
(\delta: 9.5 \%) \\
\text { of }\end{array}$ & 0 & 0 & 0 & - & 0 & $\bullet$ & $\overline{0}$ & - & 0 \\
\hline \multirow{2}{*}{$\begin{array}{c}\mathbf{S 3 1 6 \mathrm { L }} \\
(\mathrm{Fe}-17 \mathrm{Cr}-12 \mathrm{NI}-2 \mathrm{MO})\end{array}$} & Base metal & B & 0 & 8 & 0 & 8 & 0 & B & o & $\theta$ \\
\hline & \begin{tabular}{|l|}
$\begin{array}{l}\text { Weld metal } \\
\text { (10:8.8\%) }\end{array}$ \\
\end{tabular} & 0 & 0 & 0 & $\bullet$ & 0 & - & 0 & $\bullet$ & 0 \\
\hline \multirow{2}{*}{ 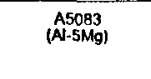 } & Base metal & B & 0 & $B$ & 0 & B & o & 8 & 0 & 8 \\
\hline & Weld metal & 0 & $\mathbf{o}$ & 0 & $\bullet$ & o & - & 0 & - & 0 \\
\hline
\end{tabular}

The value of base metal at RT is sel as the basic value (B) Decline in properties before hydrogen charging (comparison with the values of $B$ )

(9 less than $20 \%$

(0) $20 \%$ to $50 \%$

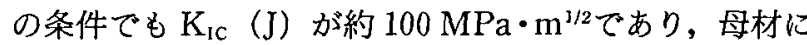
比べかなり低い值を示したが，水素チャージ量の影響は 認められなかった（図 3)。溶接金属の脆化破面では，き

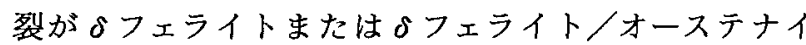
卜相界面を優先的に伝播しているのが確認された。

(2) Al 合金 (A 5083)

(1) 極低温特性

母材および溶接金属の引張特性は, $4 \mathrm{~K}$ で継手部の伸 びが母材の伸びと比較して約 60\%低下した以外は，特に 問題は認められなかった。

母材の室温でのシャルピー吸収エネルギーは約 $36 \mathrm{~J}$

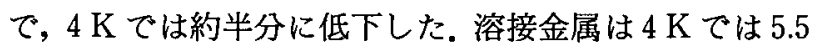
Jという非常に低い值であった.

母材の破壊勒性は, $4 \mathrm{~K}$ でも室温とほほ同じであり, 試 験温度の低下による靶性の低下は認められなかった。一 方, 溶接金属の䩚性值は室温では母材の約 75\%であり, $4 \mathrm{~K}$ では室温の約 $50 \%$ に低下する。

(2) 水素チャージの影響

室温, $4 \mathrm{~K}$ のいずれの温度においても, 引張特性, シャ ルピー衝撃特性および破壊鞄性特性は，水素チャージ処 理により変化せず，本合金の材料特性は水素チャージ処 理の影響を受けないことが確認できた。

(3) 溶接入熱の影睤

実際の大型 LNG タンクの溶接で頻繁に使用されてい る大電流 MIG 法で溶接継手を作製し，特性の評価を行 い通常の MIG 法の場合と比較した. 大電流 MIG 溶接継 手の $4 \mathrm{~K}$ での引張特性は通常 MIG 溶接継手の特性とほ とんど同じ值を示した。シャルピー吸収エネルギーは室 温, $4 \mathrm{~K}$ とも大電流 MIG の方が通常 MIGよりもやや高 い值（約 20\%）を示し，破壇靱性值は室温， $4 \mathrm{~K}$ とも大 電流 MIG の方が通常 MIGよりも約 $40 \%$ 高い值を示し

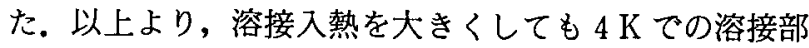
の特性劣化はないことが確認できた。

（3）水素ガス中の引張特性と疲労特性（SUS $304 \mathrm{~L}$, SUS 316 L, A 5083)
表 2 候補材の水素脆化感受性評価試験結果のまとめ

\begin{tabular}{|c|c|c|c|c|c|c|c|c|c|c|c|}
\hline \multirow{3}{*}{ Materials } & \multirow{3}{*}{ Position } & \multicolumn{9}{|c|}{ Evaluation of hydrogen-charged materials } & \multirow{3}{*}{$\begin{array}{l}\begin{array}{l}\text { Faligue } \\
\text { lite } \\
\text { (in hydro- } \\
\text { gen gas) }\end{array} \\
\text { RT }\end{array}$} \\
\hline & & \multicolumn{2}{|c|}{$\begin{array}{l}\text { Tensile } \\
\text { strength }\end{array}$} & \multicolumn{2}{|c|}{$\begin{array}{l}\text { Elongation } \\
\text { and } \\
\text { reduction } \\
\text { of area }\end{array}$} & \multicolumn{2}{|c|}{$\begin{array}{l}\text { Charpy } \\
\text { absorbed } \\
\text { energy }\end{array}$} & \multicolumn{2}{|c|}{$\begin{array}{l}\text { Fracture } \\
\text { loughness }\end{array}$} & \multirow{2}{*}{$\begin{array}{l}\begin{array}{c}\text { Faligue } \\
\text { file } \\
\text { (in alr) }\end{array} \\
\text { RT }\end{array}$} & \\
\hline & & RT & $4 \mathrm{k}$ & RT & AK & RT & $4 \mathbf{k}$ & RT & $4 \mathrm{~K}$ & & \\
\hline \multirow{2}{*}{$\begin{array}{c}\text { S304L } \\
(\mathrm{Fe}-18 \mathrm{Cr}-8 \mathrm{Ni}) \\
\mathrm{H}: 30 \mathrm{ppm}\end{array}$} & Base metal & 9 & 0 & 0 & 0 & 0 & 0 & 0 & 0 & 0 & 0 \\
\hline & Weld metal & 9 & a & 0 & 0 & 0 & 0 & - & 0 & 0 & 0 \\
\hline \multirow{2}{*}{$\begin{array}{c}\text { S316L } \\
\text { (Fe-17C-12Ni-2Mo) } \\
\text { H: }: 30 \mathrm{ppm}\end{array}$} & Base metal & $\theta$ & $\theta$ & 0 & 0 & 0 & a & 0 & 0 & 0 & 0 \\
\hline & Weld metal & 0 & 0 & 0 & 0 & o & - & - & 0 & 0 & 0 \\
\hline \multirow{2}{*}{$\begin{array}{l}\text { A5083 } \\
\text { (At.5Mg) } \\
H: 1 p p m m\end{array}$} & Base metal & D & 9 & 9 & 0 & 0 & - & 0 & 0 & 0 & 0 \\
\hline & Weld metal & $\Rightarrow$ & 9 & 0 & 0 & 0 & -. & 0 & 0 & 0 & 0 \\
\hline
\end{tabular}

室温 $80 \mathrm{~K}$ までの温度範囲で低歪み速度引張試験 (初 期歪み速度 : $\left.4.2 \times 10^{-5} / \mathrm{s}^{-1}\right)$ を行い, ステンレス鋼の引張 特性に及ほすす温度の影響について検討した。また，SUS $304 \mathrm{~L}$ の $1.1 \mathrm{MPa}$ 水素ガス中およびアルゴン中における 室温の高サイクル疲労試験 $\left(<1 \times 10^{6}\right)$ を行い, 疲労特性 に及ほす $\gamma$ フェライト相量の影響について検討した。

(1) 引張特性

常温では, SUS 304 L では水素によって伸び・絞り・ 引張強さは大きく低下した。破面形態に水素の影響が認 められ，アルゴン中では基地および 相共にディンプル 破面であったが, 水素中では基地は擬へき開破面, $\delta$ 相は へき開破面であった。一方，SUS 316 L，A 5083 ては引 張特性に劣下は認められなかった.

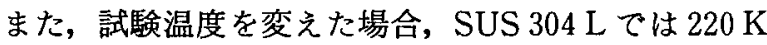
において水素によって伸び・絞りが著しく低下した. 150 $\mathrm{K}$ 以下の温度では不活性ガス中と水素ガス中の引張特 性に大きな差異は認められなかった。SUS 316 L では $220 \mathrm{~K}$ においては水素によって絞りが少し低下したが, $220 \mathrm{~K}$ より低温ではへリウム中と水紊中の引張特性に大 きな差異は認められなかった，この結果より，水素がス の影響は温度の低下にともない小さくなること，高圧水 素ガス中では, SUS 304 L は SUS 316 L に較べて高い水 素脆化感受性を示すことが明らかになった。

(2) 疲労特性

SUS 304 L の母材では，水素ガスによって破断までの 絽返し数（破断寿命）は大きく減少した。溶接金属でも

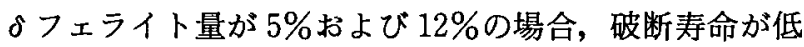

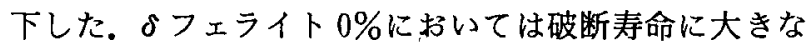
差異は認められず，疲労寿命に及沽す水素ガスの影響は

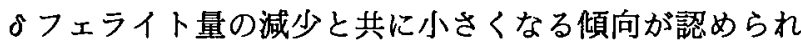
た。な扔，脆化材ではいずれも疲労き裂進展破面に水素 ガスの影響が認められた。また，SUS 316 LおよびA 5083 では，母材および溶接金属ともアルゴン中と水素が ス中の差異は認められなかった。

以上の試験結果の概要をまとめて表 1,2 に示す。表 1 


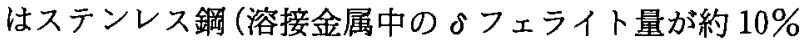
の場合）とアルミニウム（通常 MIG 溶接の場合）の水素 チャージ前の試験結果を示す. 表 2 は水素チャージ前と 後(水素量がステンレス鋼が $30 \mathrm{ppm}, \mathrm{Al}$ 合金が約 $1 \mathrm{ppm}$ の場合）の試験結果の比較を示す.

\section{4. 今後の展開}

サブタスク 6 では，来年度から液体水素雲囲気での材 料試験が可能な新試験装置を稼働させることになってい る.この装置は, 液体水素温度 $(20 \mathrm{~K})$ での引張試験, 破壊䩒性試験および疲労試験が可能な試験機（最大荷 重：25 ton)で, 今後この試験機を用いて, 新しい高靶性 溶接材料の開発を中心に候補材の液体水素温度 $(20 \mathrm{~K})$ での評価試験を実施する予定である。そして, 第 II 期で 必要となる材料デ一夕を蓄積するとともに, 候補材の液
体水素雲囲気での適用の可否を判断する予定である。ま た，並行して進めている低温脆化および水素脆化挙動の 機構解明や操業条件下での水素の侵入, 放出挙動に関す る基礎検討も継続して推進する予定である。

\section{5. おわりに}

地球環境を守るために，再生可能エネルギー源に立脚 したクリーンエネルギーシステムへの移行は, 今後確実 に進むと思われる。その際の貯蔵および輸送媒体として 水素は重要な役割を果たすことは言うまでもない，前述 したように，「WE-NET」プロジェクトは世界の注目を 集めており, 将来のエネルギ一改革実現のため今後着実 に研究開発を進めて行く必要がある。我々も全体システ ム開発における材料開発の重要性を梕識して, 最終目標 実現のため今後とも努力するつもりである.

[国際会議案内]

会議名：4 th International Seminar "Numerical Analysis of Weldability"

開催期日：1997年9月29日～10月1日

開催場所：Graz-Seggau（オーストリア）

問い合わせ先 : IIW Subcommission IXB Workinggroup "Numerical Analysis of Weldability" (主催者) and TU Graz Dep. Material Science and Welding Technology Chairman H, Cerjuk, TU Graz

Abteilung Werkatuffkande und Schweisstechnik

Kopernikusgaees 24, A-8010 GRAZ

Respoosible pergon Uernhard Schaffernak

Tel. Na: +433168737182 , Fax Na: +43 3168737187

http://www.cis.tu-grazac.al/weld/seggau.html 